\title{
La riforma del processo matrimoniale ad un anno dal Motu proprio „Mitis Iudex Misericors Iesus”, Erasmo Napolitano (red.), Libreria Editrice Vaticana 2017, ss. 233.
}

W znanej i cenionej serii „Studi giuridici” (realizowanej od 1969 roku przez Associazione Canonistica Italiana) ukazał się kolejny tom, poświęcony reformie procesu małżeńskiego w Kościele Łacińskim, dokonanej przez papieża Franciszka Motu proprio Mitis Iudex Misericors Iesus z 15 sierpnia 2015 roku (dokument wszedł w życie 8 grudnia tego samego roku). Praca ta stanowi owoc 48. Kongresu wymienionego Stowarzyszenia, który miał miejsce w Udine, w dniach 5-8 września 2016 roku.

We Wstępie Erasmo Napolitano, prezes Stowarzyszenia, wyjaśnia, że problematyka kongresu została poświęcona Motu proprio Franciszka, które wywołało zrozumiałe zainteresowanie nie tylko w wymiarze czysto akademickim czy praktycznego stosowania jego norm przez trybunały kościelne, lecz również w kontekście duszpasterskim i rodzinnym.

Autorem przedłożenia wprowadzającego w tematykę obrad kongresu („Proces małżeński i misja Kościoła”) jest kard. Francesco Coccopalmerio, ówczesny przewodniczący Papieskiej Rady ds. Tekstów Prawnych, który - w kontekście Synodu Biskupów z 2014 i 2015 roku - przedstawił panoramę najbardziej znaczących innowacji papieskiego Motu proprio. Za szczególnie doniosłe aspekty reformy uznał ułatwienie wiernym dostępu do struktur sądowych Kościoła oraz pobudzenie aktywności natury prawno-pastoralnej, przede wszystkim na poziomie peryferyjnym, łącznie z parafią.

W kolejnych dwóch tekstach ich autorzy, którzy „zestawili” reformę $\mathrm{z}$ dotychczasowym porządkiem kanonicznym, ukazują wpływ zarówno bezpośredni, jak i pośredni Motu proprio na obowiązujące prawo procesowe. 
Tak więc Hector Franceschi („Reforma i reżim dotyczący nieważności małżeństwa") wskazuje na odniesienia do nierozerwalności prawdziwego małżeństwa, a jednocześnie dostrzega ryzyko błędu, gdyby reforma była interpretowana w kluczu fałszywie duszpasterskim. Szczególną uwagę czytelnika przyciąga obszerny fragment poświecony art. 14 ,Zasad proceduralnych” (okoliczności dotyczące rzeczy lub osób, które to okoliczności dopuszczają rozpoznanie sprawy w trybie procesu skróconego przed biskupem). Słusznie autor przyjmuje, że wykaz tych okoliczności nie ma charakteru wyczerpującego, na co wskazuje dodanie na końcu $\$ 1$ „etc.”. W zakończeniu znany kanonista z Santa Croce sygnalizuje trudności, jakie mogą powstać w interpretacji niektórych postanowień dokumentu, m.in. w przedmiocie procesu skróconego, wyraża przy tym przekonanie, że zajdzie potrzeba dalszych wyjaśnień ustawodawcy.

W artykule Massimo del Pozzo („Wpływ reformy na obowiązujące prawo procesowe") autor przyjmuje, iż relację nowego i dawnego prawa procesowego znamionuje integracja i wzajemny wpływ. Podejmując namysł nad ,problemem” recepcji reformy wymieniony procesualista uznaje, iż należy respektować logikę i doświadczenie procesowe, lecz jednocześnie widzi potrzebę poważnego i pogłębionego skonfrontowania się z ewolucją regulacji prawnej, a więc przemyślenia na nowo niektórych zasad systemowych. Tak np. mając na uwadze zniesienie przez Franciszka zasady dwuinstancyjności (wymóg uzyskania dwóch wyroków za nieważnością małżeństwa), Del Pozzo wyraża obawę, że może się to „odbić” na uproszczeniu instrukcji dowodowej i jakości wyroku. Tymczasem zjawisko laksyzmu i pobłażliwości w sposób oczywisty kontrastowałoby z intencją papieża.

Za jedno z ważniejszych postanowień Mitis Iudex autor uważa podkreślenie centralnej roli biskupa diecezjalnego, ale także wikariusza sądowego (w każdym rodzaju procesu). Poza tym wskazuje doniosłość innych dyspozycji tego dokumentu - takich, jak: poszerzenie tytułów właściwości trybunału, processus brevior, sposób uczestniczenia i określenie pozycji stron, łatwe przejście do procesu super rato, ocena dowodów (zeznania stron, zeznanie jednego świadka), ograniczenie apelacji, wzmocnienie „czystości” i odpowiedniości apelacji. 
Czytelnik zapoznaje się również z relacją reformy w stosunku do podstawowych tekstów normatywnych (KPK, Instrukcja Dignitas connubii, Normy własne Roty Rzymskiej z 7 grudnia 2015 roku, Prawo własne Sygnatury Apostolskiej). Następnie autor wskazuje na koordynację i organiczny rozwój systemu (obejmującego nie tylko sprawy małżeńskie). W zakończeniu podkreślono, iż reforma Franciszka nie stanowi rewolucji czy przewrotu w systemie kanonicznym, mimo wielu nowych rozwiązań. Nowe prawo wyjaśnia, precyzuje, nie „obala” zaś dyscypliny dotychczasowej.

Zambion Adolfo jest autorem przedłożenia pt. „Porządek prawny: trybunał pierwszej instancji”, w którym omawia kwestie następujące: tytuły właściwości, trybunały pierwszego stopnia (do roku 1970, od roku 1970 do Motu proprio Mitis Iudex, Motu proprio Mitis Iudex, Mitis Iudex a ustawodawstwo partykularne, jedność materii i trybunał kompetentny), kryteria Motu proprio Mitis Iudex (centralna pozycja biskupa diecezjalnego, dostęp wiernego do trybunału w dochodzeniu nieważności małżeństwa, następstwa dla trybunału pierwszej instancji).

Kolejny rozdział: „Problemy i uwagi krytyczne w stosunku do nowej procedury" wyszedł spod pióra Eleny Di Bernardo. Po ukazaniu implementacji reformy Franciszkowej i pracach Konferencji Episkopatu Włoch (z 2016 roku), autorka skupia swoją uwagę na wpływie społecznym nowych norm (omawia tutaj m.in. medialne uwagi krytyczne pod adresem procesu skróconego, np. przyrównanie tego procesu do rozwodu), a następnie ukazuje szczególne elementy duszpasterstwa sądowego i dochodzenia przedślubnego (akcentuje tutaj potrzebę bliższego rozpoznania sytuacji osób żyjących w separacji oraz rozwiedzionych pod kątem ewentualnego wszczęcia procesu nullitatis matrimonii), analizuje „kontrowersyjną”, jak to określa, aplikację kan. $1673 \$ 2$ Mitis Iudex (obowiązek ustanowienia przez biskupa dla swojej diecezji trybunału diecezjalnego dla spraw o nieważność małżeństwa, z zachowaniem uprawnienia tegoż biskupa do przyłączenia się do sąsiedniego trybunału diecezjalnego lub międzydiecezjalnego). Owa kontrowersyjność odnosiła się do trybunałów regionalnych we Włoszech, która to kwestia została 
następnie rozwiązana (ustanowienie trybunałów międzydiecezjalnych w obrębie tej samej metropolii jest dozwolone, po zawiadomieniu Sygnatury Apostolskiej. Natomiast w przypadku ustanowienia trybunałów międzydiecezjalnych utworzonych przez diecezje należące do różnych metropolii, czyli prowincji kościelnych wymaga się zezwolenia Sygnatury Apostolskiej. Szerzej zreferowano stosowanie procesu skróconego (proces skrócony i jurysdykcja dobrowolna, warunki wszczęcia procedury - kan. 1683 Mitis Iudex, faza wstępna spraw, instrukcja dowodowa, decyzja w sprawie, apelacja, apelacja składana na zwłokę), a następnie uwzględniono procedurę bez opłat i zniesienie wymogu dwóch zgodnych wyroków.

Wybitny kanonista z Pizy, Paolo Moneta, jest autorem pracy pt. „Rola adwokata w nowym porządku procesowym”. Po zaakcentowaniu wzmocnienia roli adwokata w KPK z 1983 roku, referent ukazuje pojęcie i organizację adwokatury w KPK i w normach Konferencji Episkopatu Włoch. Ta ostatnia postanowiła, że przy każdym trybunale regionalnym mają być zatrudnieni co najmniej dwaj adwokaci stali, finansowani przez tenże trybunał, tak by mogli ofiarować swoją pomoc każdemu wiernemu, który o to prosi, bez jakiegokolwiek względu na sytuację ekonomiczną, w której się znajduje. Autor dodaje, że rozwiązanie to spotkało się z pozytywnym przyjęciem przez wiernych. W dalszym ciągu czytelnik zapoznaje się z udziałem adwokata w fazie przedprocesowej. Nieco szerzej autor traktuje o udziale adwokata w procesie skróconym, co niekiedy jest kwestionowane; zauważa, że nawet przed wydaniem wyroku przez biskupa ten ostatni może konsultować sprawę z adwokatem. Odrębny wątek wywodów Monety dotyczy figury adwokata w procesie przed Rotą Rzymską oraz zniesienia patrocinium fiduciae, a kolejny został poświęcony osobistemu zaangażowaniu się biskupa w sprawy małżeńskie oraz niewłaściwej tendencji akcentowania wymiaru prywatnego małżeństwa i pomniejszenia wymiaru prawnego stwierdzenia nieważności małżeństwa.

Giovanni Capucci i Aleksandro Fanella (odpowiednio wikariusz sądowy i sędzia diecezjalny Trybunału Metropolitalnego w Denver (USA) są autorami wykładu zatytułowanego „Urzeczywistnianie 
Motu proprio Mitis Iudex w praktyce Trybunału Metropolitalnego archidiecezji Denver - Colorado, USA". Po krótkim wprowadzeniu autorzy charakteryzują ogólnie papieskie Motu proprio, po czym przedstawiają reorganizację hierarchiczną trybunałów kościelnych na terytorium Colorado, forum kompetentne, aspekty stwarzające trudność w realizacji Motu proprio (dochodzenie wstępne, proces skrócony przed biskupem) oraz rozwiązania praktyczne w Trybunale Metropolitalnym w Denver. W zakończeniu stwierdzają, że reforma papieża Franciszka sprzyja szybkości procesów i jest słusznym ich uproszczeniem; wszystko to dokonuje się dla osiągnięcia celu ostatecznego, którym jest zbawienie dusz. Ich zdaniem, aplikacja reformy papieskiej w Trybunale Metropolitalnym archidiecezji Denver jest częściowo pozytywna. Procesy przebiegają szybciej, nieco zaś do życzenia pozostawia dochodzenie przedprocesowe (brak kompetencji na poziomie prawno-kanonicznym u osób przeprowadzających je oraz niektóre aspekty procesu skróconego. Niepokoi niedostatek proboszczów, innych duchownych, osób konsekrowanych i świeckich, a także odległości do siedziby trybunałów. Wiele kłopotu sprawia processus brevior, w szczególności rola biskupa jako sędziego, często niekompetentnego w zakresie prawno-kanonicznym. Padają tutaj pytania: czy biskup, który nie ma owych kompetencji, może spełnić dyspozycje prawne, które wchodzą w grę i wziąć pod uwagę dane faktyczne ustalone oraz dyspozycje prawne? Czy sakrament małżeństwa jest chroniony? Czy wierny, który prosi Kościół o orzeczenie ważności lub nie swojego małżeństwa, ma gwarancję otrzymania wyroku odpowiadającego prawdzie obiektywnej? W grę wchodzi również brak czasu biskupów zaabsorbowanych licznymi zajęciami. Trudność stanowi także i to, że strony nie przybywają na zeznania do siedziby trybunału, lecz jedynie odpowiadają pisemnie na postawione im pytania. $\mathrm{W}$ ten sposób proces małżeński został nadmiernie zbiurokratyzowany, co prowadzi do formalizmu. Strony często nie spotykają się w trybunale, co stwarza dystans między trybunałem i wiernymi.

„Realizacja Motu proprio Mitis Iudex w doświadczeniu niemieckich trybunałów kościelnych” to tytuł publikacji Elfridego Glaubitza, sędziego w Trybunale Metropolitalnym archidiecezji kolońskiej. 
Autor zapoznaje czytelnika ze składem wymienionego trybunału (pracuje w nim 5 obrońców węzła małżeńskiego, w tym czworo osób świeckich), podaje statystyki rozpoznanych spraw, omawia obowiązki pracowników trybunału, porusza niektóre problemy (m.in. informuje o tym, że większość biskupów niemieckich nie ma intencji prowadzenia procesów skróconych).

Mauro Bucciero, wikariusz sądowy Trybunału Kościelnego Regionalnego Sardyńskiego, prezentuje relację pt. „Urzeczywistnianie Motu proptio Mitis Iudex na Sardynii”. Ten krótki tekst zawiera uwagi autora dotyczące kompetencji wymienionego w tytule trybunału, formacji wiernych świeckich zatrudnionych w trybunale, struktur sądowych, procesu skróconego na Sardynii (miało miejsce siedem spraw).

Z kolei Pasquale Larocca, wikariusz sądowy Trybunału Kościelnego Regionalnego Pulii, jest autorem relacji pt. „Recepcja i aplikacja Mitis Iudex w regionie kościelnym pulijskim". Przytacza w niej uzgodnienia Konferencji Biskupów Pulii zawarte w „Nocie” z 7 grudnia 2015 roku.

Wręcz lapidarny jest tekst Antonio De Grandis, wikariusza sądowego Trybunału Kościelnego Regionalnego Abruzzo-Molise („Aplikacja reformy kanonicznego procesu małżeńskiego w Trybunale Kościelnym Regionalnym Abruzzo-Molise”), w którym porusza kwestie dotyczące fazy przedprocesowej, czyli duszpasterskiej, fazy sądowej oraz procesu skróconego.

Analogiczne są przedłożenia: Vincenzo Murgano, wikariusza sądowego Trybunału Kościelnego Regionalnego Sycylijskiego; Luchi Sansalonego, wikariusza sądowego w Trybunale pierwszej instancji Wikariatu Miasta; Ettora Signorilego, wikariusza sądowego Trybunału Kościelnego Piemonckiego, wreszcie Vincenzo Varonego, wikariusza sądowego Trybunału Kościelnego Kalabryjskiego.

Zaprezentowaną pracę należy uznać za bardzo pożyteczną, przybliża bowiem czytelnikowi sens i znaczenie reformy procesu małżeńskiego dokonanej przez papieża Franciszka Motu proprio Mitis Iudex z 15 sierpnia 2015 roku. Poszczególne wątki tematyczne wymienionego dokumentu zostały poddane szerszej analizie w kontekście 
dotychczasowych uregulowań kodeksowych. Dużo uwagi poświęcono zarówno genezie Motu proprio, jak i poszczególnym kwestiom tam poruszonym i uregulowanym.

Pewnym mankamentem opracowania są powtórzenia niektórych spraw (m.in. processus brevior) w kilku referatach wygłoszonych podczas kongresu włoskich kanonistów. Można było dokładniej określić zakres poszczególnych kwestii poruszanych przez autorów.

Z pewnością kolejny tom serii Studi giuridici zainteresuje zarówno wykładowców kanonicznego prawa procesowego, jak i praktyków sądowych. Niezależnie zaś od wszystkiego, praca ukazuje szeroką panoramę kwestii uregulowanych w Motu proprio Mitis Iudex Misericors Iesus.

ks. Wojciech Góralski

ORCID: 0000-0001-6548-4120 